\title{
Creating shared value in the buyer-supplier relationship through the implementation of sustainability requirements
}

\author{
T.M. Meulensteen* \\ Unilever, \\ Twentsestraat 13, 7417BL Deventer, The Netherlands \\ Email: meulensteen.tessa@gmail.com \\ *Corresponding author
}

\section{Walter J.V. Vermeulen}

Copernicus Institute of Sustainable Development, Utrecht University,

P.O. Box 80115, 3508 TC Utrecht, The Netherlands

Email: W.J.V.Vermeulen@uu.nl

\section{S. Meerman}

Formerly of: Unilever,

Zuidlaarderweg 51, 9479 TH Noordlaren, The Netherlands

Email: s.meerman@outlook.com

\begin{abstract}
This research aims to find a relationship between governance strategies to involve suppliers in sustainability implementation and the creation of shared value in the buyer-supplier relationship. The implementation of Unilever's Sustainable Living Plan has been taken as a case study. This allows for the analysis of the nature of the buyer-supplier interactions. The different partners in this relationship were asked to fill out questionnaires. Correlation and regression analyses were used to quantify the relationship between the governance strategy which is most dominant and the creation of shared value. It is concluded that cooperative strategies rather than coordinating strategies are best able to create shared value. This is supported by strong information transfer between supply chain partners and the content of the message. The creation of shared value requires that both parties already see and experience the benefits of the implementation of the sustainability requirements during the implementation, and not only afterwards.
\end{abstract}

Keywords: environmental issues; social responsibility; supply chain management; sustainability; survey methods; quantitative data analysis; regression analysis.

Reference to this paper should be made as follows: Meulensteen, T.M., Vermeulen, W.J.V. and Meerman, S. (2016) 'Creating shared value in the buyer-supplier relationship through the implementation of sustainability requirements', Global Business and Economics Review, Vol. 18, No. 6, pp.656-678. 
Biographical notes: Tessa Meulensteen is a Quality Manager in a Unilever factory. Her work focuses on quality management in the factory, and the broader supply chain. Her background is in governance for sustainability and quality excellence management.

Walter J.V. Vermeulen is an Associate Professor in Environmental Social Science at Utrecht University since 1996. His work focuses on design, implementation and effectiveness of new strategies for improving the environmental and socio-ethical performance of production and consumption systems by means of co-production of sustainable development strategies. He is also the President of the International Sustainable Development Research Society (http://www.isdrs.org).

Sikke Meerman currently is an independent consultant for agricultural supply chains and sustainable practice. Formerly employed by Unilever as a Raw Material Supply Chain Development Director and Senior Agronomist. He graduated from Wageningen University in the areas of crop production and plant breeding in 1975. His career encompassed leading roles in farmer education, extension, raw material supply, plant breeding and seed supply in arable and vegetable crops globally.

\section{Introduction}

Companies are increasingly being held accountable for the impact of their activities on society and the environment (Porter and Kramer, 2006, 2011; Vermeulen, 2015). This impact goes beyond the processes of a company itself, but includes the full supply chain. Sustainable supply chain management is a way for companies to address the impact of production processes in the supply chain in order to improve the environmental and societal conditions within those chains (Vermeulen, 2010). Sustainable supply chain management is two-sided:

a the technical specifications of the standards to which supply partners agree to adhere

b the management and coordination of the actors involved (Goldbach et al., 2003).

Technical specifications of standards have been addressed in many different literature studies (Opara, 2002; Angel and Rock, 2005; Hutchins and Sutherland, 2008; Searcy, 2011; Heikkurinen and Forsman-Hugg, 2011; Roca and Searcy, 2012), but according to Goldbach et al. (2003) the main challenge remains with the management and coordination of the chain actors involved.

Supply chain relations have been researched from different angles:

a from a sustainable supply chain management point of view (Porter and Kramer, 2006, 2011; Seuring and Müller, 2008; Bitzer et al., 2008; Vermeulen, 2010)

b in the facilitation of other supply chain capabilities in general (Wagner and Krause, 2009)

c more specifically, such as in quality (Humphreys et al., 2011), lead times (Hult et al., 2004; Wagner and Krause, 2009; Humphreys et al., 2011), innovation (Carey et al., 
2011; Humphreys et al., 2011), costs (Carey et al., 2011; Humphreys et al., 2011) and commitment (Prahinski and Benton, 2004; Krause et al., 2007).

In these studies it is concluded that interactions within the supply chain have a large influence on the performance of the different parties within the supply chain but also on the supply chain as a whole (Seuring and Müller, 2008; Paulraj, 2011).

Porter and Kramer $(2006,2011)$ argue that collaboration in supply chain management should lead to win-win situations. The key is to create shared value within the supply chain. The benefit of shared value becomes apparent when sustainable supply chain management is considered as a relational capability. Relational capabilities grow over time and are hard to imitate (Paulraj, 2011; Bastl, 2013). Because of this unique relational capability, it will generate a competitive advantage for the companies involved (Gereffi et al., 2005; Gold et al., 2010). However, the question of how collaboration processes create sustainability as a unique capability - and thereby add value for the parties involved - is not yet fully answered (Fawcett, 2012).

There are several forms of relationship management in supply chains. Muller and Vermeulen (2012) look at the difference between pushing and sharing strategies. Pushing is described as 'a unilateral, prescriptive approach, mirroring a paternalistic value system, in which a company prescribes norms of social responsible behaviour at ground level' [Muller and Vermeulen, (2012), p.128]. In contrast, sharing is an approach which is characterised by its bilateral and collaborative approach where businesses and NGOs work together in order to improve working conditions. Muller and Vermeulen (2012, p.142) conclude that "the participative approach is the more successful strategy to attain long-term sustainable change".

However, not every partner in the supply chain is equally able to influence which strategy is used. A determining factor is the positioning of the lead firm (Bitzer et al., 2008). Lead firms in a supply chain are companies which are able to set and/or enforce parameters under which other actors in the chain operate - such as sustainability standards [Humphrey and Schmitz, (2001), pp.21-22]. Two supply chain types are distinguished, based on the position of the lead firm: producer-driven and buyer-driven (Gereffi, 1999). In producer-driven supply chains, lead firms are located on the supply side of the supply chain. In buyer-driven supply chains the lead firm is positioned on the demand side of the chain (Gereffi, 1999).

Lead firms can take several governance strategies to affect supply chains (Dyer and Nobeoka, 2000; Krause et al., 2007). These governance strategies differ in the extent to which they require interaction and explicit coordination by the lead firm (Gereffi et al., 2005). The choice of a governance strategy influences the levels and complexity of information which can be transferred in a supply chain (Dyer and Nobeoka, 2000). When the creation of shared value is taken as a prerequisite for sustainable supply chain management, and lead firms use governance strategies to implement sustainable supply chain management the question arises:

- How do governance strategies used by lead firms to involve suppliers in sustainable supply chain management affect the creation of shared value between supply chain partners?

This article aims to answer this question by combining two distinct strands of research: sustainable supply chain management research and buyer-supplier relations research. Sustainable supply chain literature focuses on efficiency, chain relations and the 
implementation of sustainability standards at chain level, but it fails to address issues at a company level (Hamann, 2004; Hughes, 2005; Hills and Welford, 2005; Hess and Coe, 2006; Palpacuer, 2006; Vermeulen and Ras, 2006; Ansett, 2007; van der Heijden et al., 2010; Golicic and Smith, 2013). Buyer-supplier relations research focuses on company level, but addresses issues of quality, cycle time and cost reduction (de Bakker and Nijhof, 2004; Benton and Maloni, 2005; Wagner and Krause, 2009). The main question of this article requires a single buyer as a starting point, to enable the assessment of the different governance strategies used with suppliers and their effect on the creation of shared value.

\section{Shaping supply chain interactions}

\subsection{Supply chain governance strategies}

Governance strategies enable lead firms to shape supply chain interactions for the implementation of sustainability standards in the chain (Gereffi et al. 2005). Scholars have identified several different strategies (Gereffi et al., 2005; Hughes, 2005; Krause et al., 2007; Wagner and Krause, 2009).

The arm's length strategy is characterised by contractual relations between firms based on competitive bidding, weak social ties and detached social relationships (Hughes, 2005). This approach is often used in supply chains with a large number of producers and where standard products are manufactured (Dolan and Humphrey, 2004; Gereffi et al., 2005). The need of intensive communication between two firms in such chains is low (Hughes, 2005).

When complexity of information exchange is high it becomes profitable for firms to develop long-term relationships with suppliers. Long-term relationships facilitate improved supplier capabilities by creating learning routines and managing knowledge flows (Dyer and Nobeoka, 2000). These relationships develop in contexts of strong social ties, which require intensive communication (Preuss, 2005; Humphreys et al., 2011). Governance strategies which facilitate the development of strong social ties are called supplier development strategies (Wagner and Krause, 2009). There are two types of supplier development strategies: indirect supplier development strategies and direct supplier development strategies (Hughes, 2005).

The indirect supplier development is characterised by relationships of trust, collaboration and close interpersonal ties between buyers and suppliers. However, the relationships between supply chain partners are not equal; one supply chain member has the power to decide on the terms of implementation (Hughes, 2005). The indirect supplier development strategy is characterised by interactions which are dominated by the lead firm. This governance strategy is related to the 'pushing'strategy as mentioned by Muller and Vermeulen (2010). Typical indirect supplier development activities are supplier evaluation and the one-sided provision of explicit information about the supplier's evaluation results (Prahinski and Fan, 2007). These activities are more commonly used in supplier management and can precede and enable direct supplier development (Wagner and Krause, 2009).

The direct supplier development is related to the 'sharing' strategy as characterised by Muller and Vermeulen (2010) and shows a strong mutual involvement. This mutual involvement facilitates an environment in which complex information can be transferred 
between supply chain members. Activities of direct supplier development are related to the provision of specialised technical, process or managerial knowledge and the interactive sharing of knowledge by the exchange of human assets (Wagner and Krause, 2009). The governance strategies are summarised in Table 1.

Table 1 Characteristics of strategies

\begin{tabular}{|c|c|c|c|c|}
\hline Strategy & Characteristics & $\begin{array}{c}\text { Power } \\
\text { asymmetry }\end{array}$ & $\begin{array}{c}\text { Information } \\
\text { complexity }\end{array}$ & $\begin{array}{l}\text { Media } \\
\text { richness }\end{array}$ \\
\hline $\begin{array}{l}\text { Arm's length } \\
\text { strategy }\end{array}$ & $\begin{array}{l}\text { - } \text { Weak social ties } \\
\text { - } \text { Relations based on } \\
\text { competitive bidding } \\
\text { - } \quad \text { Many suppliers and many } \\
\text { buyers } \\
\text { - }\end{array}$ & - Low & - Low & - Low \\
\hline $\begin{array}{l}\text { Indirect supplier } \\
\text { development } \\
\text { strategy }\end{array}$ & $\begin{array}{l}\text { - } 1 \text {-sided development } \\
\text { - } \quad \text { Evaluation }\end{array}$ & - High & - High & - Medium \\
\hline $\begin{array}{l}\text { Direct supplier } \\
\text { development } \\
\text { strategy }\end{array}$ & $\begin{array}{l}\text { - Mutual involvement } \\
\text { - Training and assistance }\end{array}$ & - High & - High & - High \\
\hline $\begin{array}{l}\text { Communication } \\
\text { strategy }\end{array}$ & $\begin{array}{l}\text { - } \\
\text { - } \\
\text { Frequent use of diverse } \\
\text { media tools, such as } \\
\text { email, phone and } \\
\text { newsletters. }\end{array}$ & - Medium & - High & - Medium \\
\hline
\end{tabular}

Information complexity plays an important role in which governance strategy is chosen for the coordination of chain actors (Krause et al., 2007).

Complex information can be transferred by the use of 'rich' information. Rich information refers to "the ability of information to change understanding within a time interval" [Daft and Lengel, (1986), p.560]. Different media can process different levels of information richness. The difference in richness is related to the capacity for immediate feedback, the number of cues and channels utilised by the medium, personalisation and language variety (Daft and Lengel, 1986; Prahinski and Benton, 2004). Different governance strategies can handle different levels of information and media richness.

Sustainability standards contain information which is new to suppliers; hence they are complex. In this research, we have chosen to add a third strategy to the supplier development strategies; the communication strategy. The communication strategy focuses on the frequency and diversity of media tools which are used to transfer information in a supply chain. The communication strategy is also used in a context of strong social ties, because it is used to transfer complex information, but - other than in the direct supplier development strategy - face-to-face interaction is not required for the use of the tools in the communication strategy.

For a full spectrum of governance strategies, the arm's length strategy is also included. This governance strategy is translated as the use of contracts to specify demands. This strategy is low in both information and media richness. In Table 1, the characteristics of the governance strategies are provided in one overview. 


\subsection{Model and hypotheses}

\subsubsection{Mediating effects}

This research focuses on how improved supplier performance can be facilitated by the use of different governance strategies. Supplier performance is defined as the performance of a supplier on the implementation of sustainability standards in its own processes and the further supply chain. When the standards are correctly implemented they will lead to shared value in the buyer-supplier relationship. Sustainability can be used as a unique capability and as such provides a competitive advantage to the supply chain partners.

Governance strategies are used to influence supplier implementation of sustainability requirements in their production processes. This is not a direct effect, but the relation between governance strategies and supplier performance is mediated by the level of clarity, improved capabilities and cost perception of a supplier.

Levels of clarity add to the success of implementation because they clarify expectations in the buyer-supplier relation (Prahinski and Benton, 2004; Humphreys et al., 2011).

Capabilities are related to levels of clarity. According to the resource-based view, capabilities add to the competitive advantage of companies (Gold et al., 2010). They are important to companies in environments where demands on products constantly change, because they facilitate a company's ability to adapt its resources to these changing demands (Gold et al., 2010). The implementation of sustainability requirements in supply chains creates a context of changing demands on products. In this context, capabilities are considered preconditions of 'successful environmental and social collaboration' [Gold et al., (2010), p.237]. This can lead to unique capabilities, which provide the involved parties with a competitive advantage (Gereffi et al., 2005; Porter and Kramer, 2006, 2011). This competitive advantage is a shared value which will only exist if the relationship between the supply chain partners continues to be successful (Porter and Kramer, 2006, 2011).

The implementation of sustainability standards requires suppliers to change their production processes, which involves short-term costs. Furthermore, these costs are non-transferable which means that the investor risks losing the investment (Krause et al., 2000, 2007). When a supplier expects to have long-term benefits from the implementation of the sustainability standard, this risk is decreased because it is outweighed by the benefits. However, when suppliers do not expect additional benefits from sustainability implementation, they will most likely try to avoid incurring these costs as much as possible. As a result, cost perception of suppliers affects the implementation.

\subsubsection{Trust, dependency and power}

Trust, dependency and power in the relationship also affect the development of clarity, mutual capabilities and a balanced cost-benefit perception (Gereffi et al., 2005; Gligor, 2012). Trust is defined as "the willingness of a party to be vulnerable to the actions of another party based on the expectation that the other party will perform a particular action important to the truster, irrespective of the ability to monitor or control that other party" [Mayer et al., (1995), p.712 in Skandrani et al., (2011), p.94]. One aspect of the 
willingness to be vulnerable is the level of information which is shared between supply chain partners, which influences clarity between supply chain partners (Skandrani et al., 2011; Paulraj, 2012).

Vulnerability is not only related to sharing information, but also to the willingness to incur short-term costs in a context of uncertain long-term benefits (Krause et al., 2000; Humphreys et al. 2004). As seen before, suppliers need to incur short-term costs, with uncertain long-term benefits. Suppliers will only be willing to make such investments when they expect to continue the relationship with the buyer. This expectation is based on the trust of a supplier in a buyer.

The level of dependency and power inequality between supply chain partners is related. The resource dependency theory (Frooman, 1999) argues that dependency and the performance of supply chain partners are related (van Huijstee, 2010).

Related to dependency is power. The focus in this article is on the nature of power and how it is exercised (Bair and Gereffi, 2001; Terpend et al., 2011). Benton and Maloni (2005) stress that misuse of power leads to the underperformance of chain actors. At the same time they conclude that a judicious use of power can benefit supply chain performance (Benton and Maloni, 2005). Power is closely related to which governance strategies a firm decides to use (Gereffi et al., 2005). In Table 1, the level of power asymmetry is specified for each of the four governance strategies. The relations between governance strategies, relationship characteristics on the one side and clarity, capabilities and cost perception on the other, as well as the relations between those mediating effects and supplier performance, are assessed through the following model (Figure 1). In all the relations a positive effect is hypothesised.

Figure 1 Conceptual model (see online version for colours)

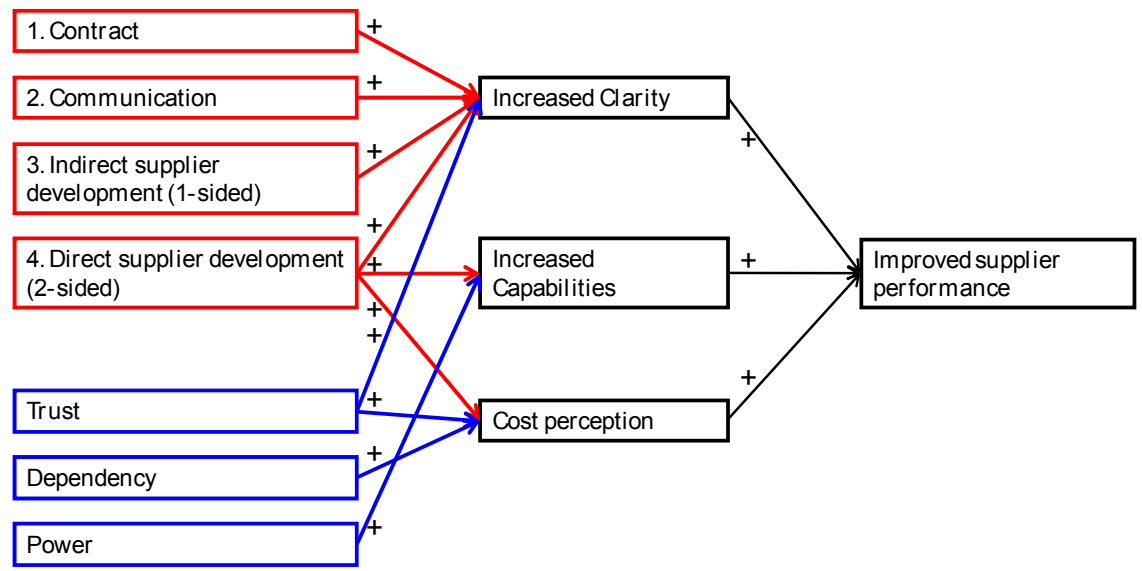

\section{Implementing Unilever's sustainability plan}

Unilever is used as a case study to test the model. Unilever is a multinational company producing foods, beverages, personal care and home care products (Unilever, 2010a). The focus of the research is on the foods division of the Unilever business. 
In 2010, Unilever developed a new vision: to double the size of the business, while reducing its environmental footprint and increasing its positive social impact. The Unilever Sustainable Living Plan (USLP) is the roadmap to reach this goal by 2020 . One of the aims in the USLP is to sustainably source $100 \%$ of the raw agricultural material which Unilever uses (Unilever, 2010c).

The definition of sustainable agriculture is developed in the Unilever sustainable agriculture code (SAC). In order to reach $100 \%$ sustainable sourcing of agricultural materials, all suppliers delivering raw agricultural materials need to comply with this code. The requirements in the SAC are designed for a farm level implementation and the first-tier suppliers to Unilever are responsible for this implementation. As a result, even though the direct interaction is between Unilever and its first-tier suppliers, the full supply chain is addressed in the implementation of the SAC (Unilever, 2010b).

There are two main reasons to focus on Unilever in this research. First, due to its global nature Unilever is involved in many different supply chains. Second, Unilever only started with SAC implementation in 2010. At the time this research was performed the relationships between Unilever and its suppliers were renegotiated to implement the $\mathrm{SAC}$. The use of different governance strategies is part of this renegotiation.

Unilever uses the different governance strategies to involve its suppliers in SAC implementation. It uses both 'pushing' and 'sharing' methods, which allows for a comparison of the effect of the different governance strategies on the implementation of the SAC.

\section{Research methods}

\subsection{Data collection and sample}

The relationship between Unilever and suppliers was assessed by the use of a survey. This survey was sent to suppliers, procurement managers and consultants, which work together on the implementation of Unilever's sustainability code. Each group of respondents received a questionnaire which addressed the strategies, relationship characteristics, intermediate effects and supplier performance. Questionnaires were different in order to create a group-specific perspective on the questions.

The sample for the survey is based on location and size of the supplier. None of the suppliers has an exclusive relationship with Unilever. The survey was sent to 100 suppliers and the affiliated procurement managers and consultants. Out of the 100 suppliers in the sample, 89 are vegetable suppliers. As a result, the conclusions of this research are most applicable to vegetable suppliers.

The survey design was such that all three surveys needed to be returned in order to have a complete case. 73 Surveys were returned by procurement managers, 56 by the consultants and 60 by the suppliers. However, this resulted in a total of 32 complete sets; a small sample size. Sample size determines the effect size which can be measured. With this sample only large size effects can be measured [Field, (2005), p.58].

The questionnaire consists of statements in combination with five point Likert scales and tick-in-the-box questions with fixed answer categories. One open question was added at the end of the questionnaire. This question addressed the main barriers to implementing the SAC. Adding this question provided respondents with the opportunity to give personal feedback. 
Wherever possible, the questionnaire was built of pre-tested questions used in previous research (Terpend and Ashenbaum, 2012; Krause et al., 2007). When questions were not readily available the constructs were translated into questions. These questions were validated by:

a the use of an extensive literature review

b pre-tested by the person who coordinates the implementation of Unilever's sustainability code and two academics in the field of sustainable supply chain management.

\subsection{Statistical analyses}

Two samples are used in this research: one with all the returned questionnaires and one with only the questionnaires which form a set between the supplier, procurement manager and the consultant. In order to account for a difference in distribution of scores, both samples are compared. The distribution of scores between the two samples is similar. Therefore the results of the analyses of the two complementary datasets can be used simultaneously. The complete dataset is used in order to reduce the granularity of the data as much as possible and to keep all the data in the analysis. In the assessment of supplier performance all the data is used. In the correlation and regression models only the cases in which three questionnaires were returned were used.

The use of the governance strategies in each relationship between Unilever, suppliers and consultants was scored based on the constructs around media richness and level of cooperation in the relationship. Kendall's $\tau$ is used as the coefficient for bivariate correlation analysis. When data is not normally distributed and the sample size is small, Field advises to use Kendall's $\tau$ [Field, (2005), p.181].

In addition, five different regression models are used to test the overall model of this research. For each regression model the variables are entered in a forced hierarchical way (Field, 2005). All variables are entered simultaneously. For both the correlation and multiple regression analysis it was decided to use a 0.10 significance level (Allison, 1999; Ras and Vermeulen, 2009).

\section{Results}

\subsection{Supplier performance and the use of governance strategies}

A first step in measuring the relationship between supplier performance and governance strategies is to assess the current supplier performance and the used governance strategies.

Supplier performance is measured as the implementation of sustainability requirements at the farm level. This implies that suppliers implement the requirements in the full supply chain. Suppliers were asked to score the implementation of the sustainability requirements on separate topics at farm level; both at this moment and as expected in the future. In Figure 2, the compliance with the separate topics at farm level as scored by the suppliers is shown. 
Figure 2 Supplier performance implementation at farm level

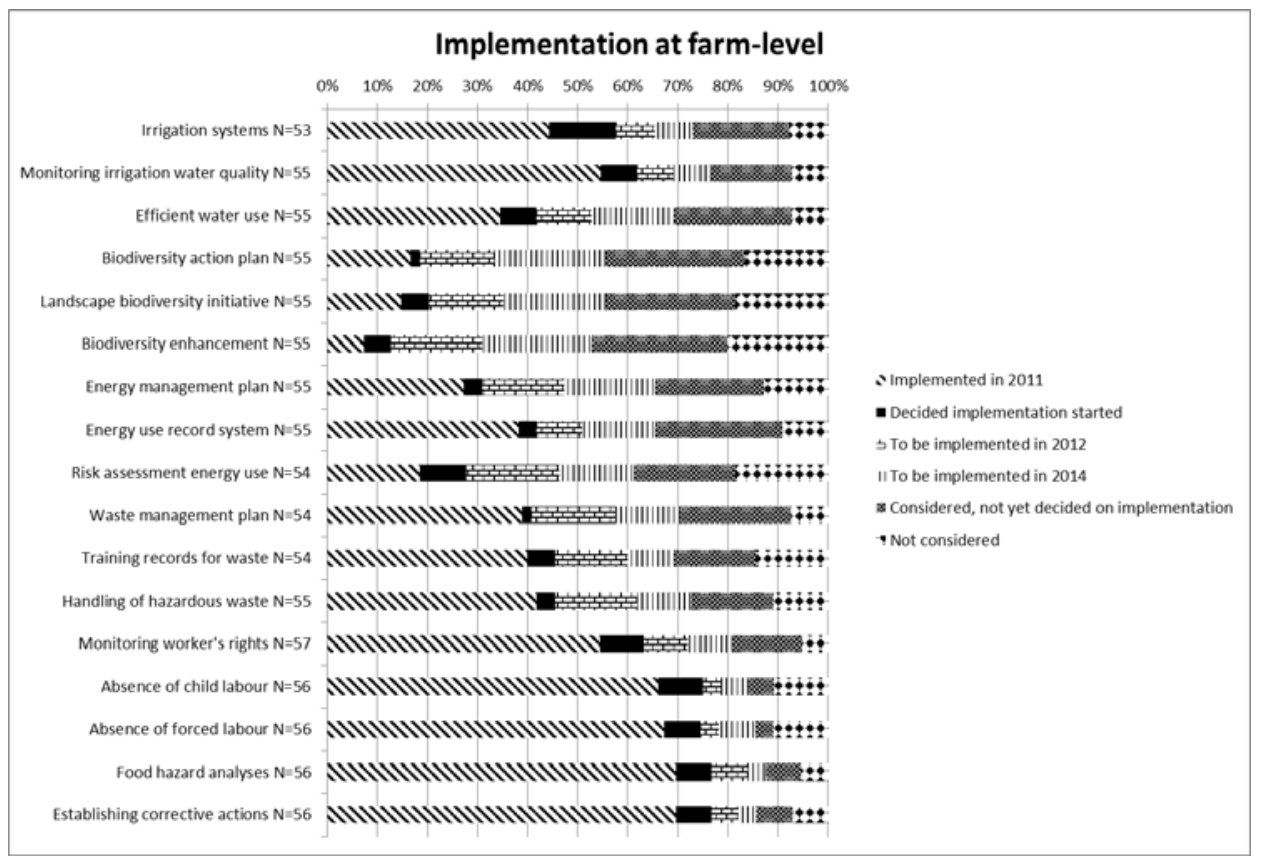

The aggregated measure of supplier performance shows a large variation in scores. Hence, suppliers are not all at the same level of implementation at this moment.

The four distinguished governance strategies - contract, communication, indirect supplier development and direct supplier development - are not always used with all suppliers. The contract strategy is not commonly used with the suppliers in this sample; over $90 \%$ of the suppliers claim that they do not work with long-term contracts.

In this sample, whilst the contract strategy is not commonly used, the other three governance strategies - communication, indirect supplier development and direct supplier development - are all used to influence the suppliers.

The communication strategy is used with all the suppliers in the sample; however, the frequency and type of communication tools which are used is different between the suppliers. Suppliers are not equally familiar with all the topics. The communication strategy can play a strong role in facilitating this familiarity and thereby help the implementation. Also, the diversity in communication tools which are used in the buyer-supplier relationship is distributed among the sample, but is skewed towards the lower values. This indicates that in most of the buyer-supplier relationships only a few media tools are used and that frequency of usage is not standard. Finally, a difference was found between the communication of the standard as a whole and the separate topics. Information about the standard as a whole is shared on a more personal one-to-one basis, while information about specific topics is communicated via websites and not directed to suppliers specifically. This indicates that the communication strategy is used - and elements are strategically chosen - to influence the way a supplier implements the sustainability requirements. It also indicates that suppliers have multiple ways of finding 
information, which are not always part of the communication within the buyer-supplier relationship.

Figure 3 Distribution of scores per strategy (see online version for colours)

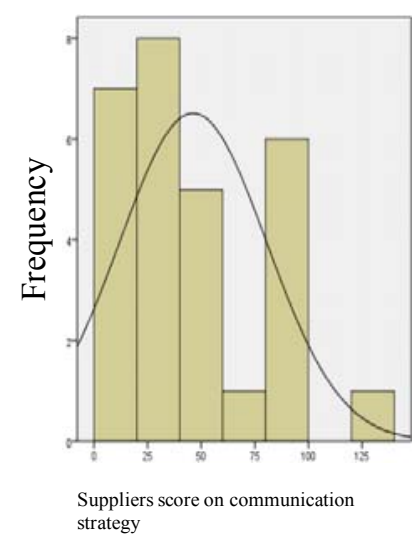

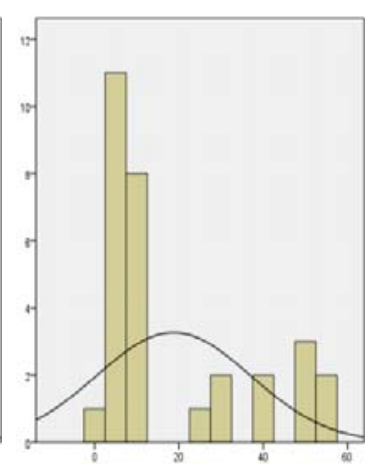
Suppliers score on indirect supplier
development strategy

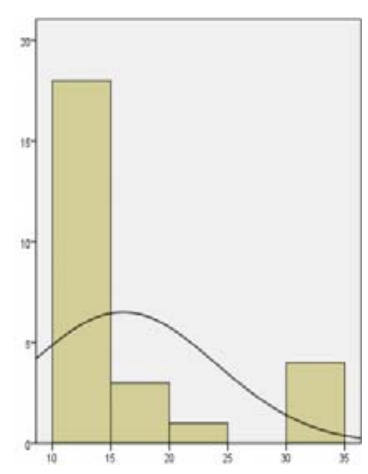

Suppliers score on direct supplier development strategy

The indirect supplier development strategy is used with $82 \%$ of the suppliers in the sample. A first evaluation of the supplier's status is done at the fields of several pilot farms; hence field and farms visits and supplier evaluation overlap during the first period of implementation. The distribution on scores of the indirect supplier development strategy comes mostly from the follow-up sessions. The indirect supplier development strategy is used for the implementation of the standard as a whole, rather than for the topics separately.

The direct supplier development strategy shows the largest distribution in scores among the suppliers. Some of the most intensive methods of engagement are used in only a very few buyer-supplier relationships. Other methods are less media rich, but are used with a much larger group of suppliers. The large distribution in scores of elements of the direct supplier development strategy enables us to assess the relationship between the direct supplier development strategy and the implementation of sustainability requirements by suppliers. It does not allow the assessment of the separate aspects of the direct supplier development methods.

The communication, indirect supplier development and direct supplier development strategies are all used to influence suppliers to implement sustainability requirements. However, the extent and intensity differs from supplier to supplier. This means that the effect of the governance strategies on the implementation of the sustainability requirements can be measured with this data set.

\subsection{Facilitating supplier implementation of sustainability standards}

In the developed model the effect of governance strategies on improved supplier performance is mediated by the levels of clarity, capabilities and cost perception of the supplier.

Significant correlations are found between clarity and improved supplier performance, as well as between cost perception and improved supplier performance. No significant correlation is found between increased capabilities and improved supplier 
performance (see Table 2). However, the sample size which is used is small, so an effect could still exist, but is too small to measure with the used sample.

Table 2 Significant correlations between the intermediate effects and improved supplier performance

\begin{tabular}{llccc}
\hline \multicolumn{2}{l}{ Correlations (Kendall's T) } & Clarity & $\begin{array}{c}\text { Cost perception- } \\
\text { familiar with funding }\end{array}$ & $\begin{array}{c}\text { Cost perception } \\
- \text { use of funding }\end{array}$ \\
\hline Improved & Correlation coefficient & $.273^{* *}$ & $.269^{*}$ & $.462^{* * *}$ \\
supplier & Sig. (1-tailed) & .027 & .051 & .003 \\
performance & $\mathrm{N}$ & 31 & 27 & 26 \\
\hline
\end{tabular}

Notes: *Correlations are significant at a 0.10 level (1-tailed).

**Correlations are significant at a 0.05 level (1-tailed).

***Correlations are significant at a 0.01 level (1-tailed).

The unique relationship between clarity and cost perception with improved supplier performance is tested via a regression model. In this model, cost perception is split in the use of funding and the perception of suppliers about the costs of the implementation. The measure of a supplier's perception of the costs related to the implementation is not significantly correlated with improved supplier performance. Only the use of funding is tested in the regression model.

Table 3 Multiple regression predicting improved supplier performance

\begin{tabular}{lcc}
\hline Dependent variable $(n=31)$ & \multicolumn{2}{c}{ Improved supplier performance } \\
\hline \multirow{2}{*}{ (Constant) } & $\beta$ & $R^{2}=0.295$ \\
\cline { 2 - 3 } & 0.069 & Sig. 0.000 \\
\hline Clarity & $0.503^{* *}$ & 0.745 \\
Use of funding & 0.024 \\
\hline
\end{tabular}

Notes: *Regressions are significant at a 0.10 level (1-tailed).

**Regressions are significant at a 0.05 level (1-tailed).

$* * *$ Regressions are significant at a 0.01 level (1-tailed).

The clarity in the relationship between a buyer and a supplier and the use of funding together explain $29.5 \%$ of the variance in improved supplier performance (see Table 3). However, only the use of funding has a significant and separable effect on improved supplier performance. This shows that seeing the direct benefits to implementing sustainability requirements in supply chains is a strong incentive for suppliers to actually implement those requirements.

This does not discount the other mediating factors. Clarity, capabilities and cost perception show high correlations with each other (see Table 4). Suppliers can only be aware of the possibility of using a fund, when information about this fund is transferred to them. Similarly, when a message is not clearly conveyed to a supplier, it is also most likely not useful to the supplier; hence the supplier cannot use the information to improve its capability to implement the set requirements. Therefore, low clarity levels are related with low capability levels. Finally, the creation of capabilities is costly - even though those costs are intangible in nature. Therefore, cost perception and capabilities are related. 
Table 4 Correlations between the intermediate effects

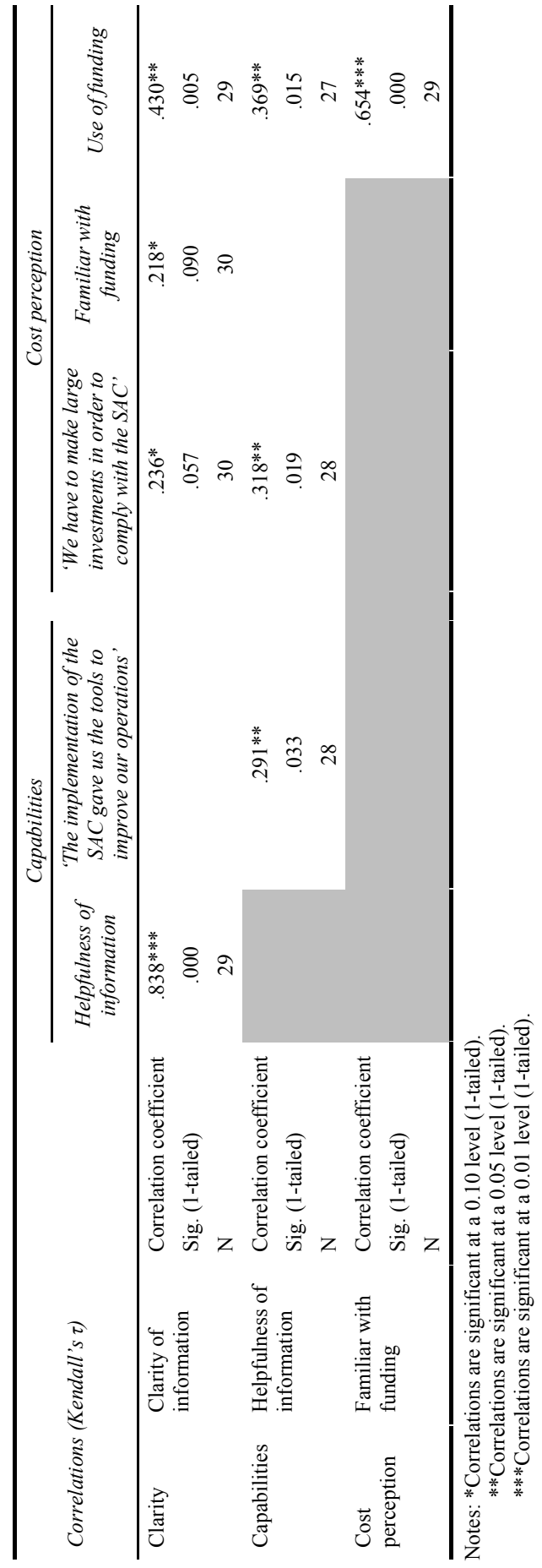


Due to the high correlations between the intermediate effects, it is likely that the level of capabilities also has an effect on improved supplier performance through the other two mediating variables. Clarity, capabilities and cost perception need to be met simultaneously to have the largest effect. Therefore, they are prerequisites rather than intermediate effects. At the same time, even though the use of funding is the only mediating effect which has a unique relation with improved performance, it still is related to the other intermediate effects. Therefore, the focus should be on improving all the intermediate effects, but the largest effects will occur when the use of funding - or similar methods -is emphasised.

A buyer can choose different governance strategies to improve levels of clarity, capability and cost perception. The contract strategy is not used by Unilever and therefore not tested in this model. Many significant correlations are found between the governance strategies and clarity, capabilities and cost perception (see Table 5). Both clarity and capabilities are significantly influenced by all three governance strategies communication, indirect supplier development and direct supplier development. Cost perception is significantly affected by both the communication and the direct supplier development strategies.

Table 5 Significant correlations between the governance strategies and the intermediate effects

\begin{tabular}{|c|c|c|c|c|}
\hline \multicolumn{2}{|c|}{ Correlations (Kendall's $\tau$ ) } & \multirow{2}{*}{$\frac{\text { Communication }}{.453^{* * *}}$} & \multirow{2}{*}{$\begin{array}{c}\begin{array}{c}\text { Indirect supplier } \\
\text { development }\end{array} \\
.412^{* * *}\end{array}$} & \multirow{2}{*}{$\begin{array}{c}\begin{array}{c}\text { Direct supplier } \\
\text { development }\end{array} \\
.568^{* * *}\end{array}$} \\
\hline Clarity & $\begin{array}{l}\text { Correlation } \\
\text { coefficient }\end{array}$ & & & \\
\hline & Sig. (1-tailed) & .001 & .001 & .000 \\
\hline & $\mathrm{N}$ & 28 & 30 & 26 \\
\hline \multirow[t]{3}{*}{ Capabilities } & $\begin{array}{l}\text { Correlation } \\
\text { coefficient }\end{array}$ & $.494 * * *$ & $.502 * * *$ & $.486^{* * *}$ \\
\hline & Sig. (1-tailed) & .000 & .000 & .001 \\
\hline & $\mathrm{N}$ & 28 & 30 & 26 \\
\hline \multirow[t]{3}{*}{ Use of funding } & $\begin{array}{l}\text { Correlation } \\
\text { coefficient }\end{array}$ & $.300 * *$ & & $.233^{*}$ \\
\hline & Sig. (1-tailed) & .036 & & .087 \\
\hline & $\mathrm{N}$ & 26 & & 25 \\
\hline \multirow{3}{*}{$\begin{array}{l}\text { "We have to } \\
\text { make large } \\
\text { investments in } \\
\text { order to comply } \\
\text { with the SAC" }\end{array}$} & $\begin{array}{l}\text { Correlation } \\
\text { coefficient }\end{array}$ & $.408 * * *$ & & \\
\hline & Sig. (1-tailed) & .003 & & \\
\hline & $\mathrm{N}$ & 27 & & \\
\hline
\end{tabular}

Notes: *Correlations are significant at a 0.10 level (1-tailed).

**Correlations are significant at a 0.05 level (1-tailed).

***Correlations are significant at a 0.01 level (1-tailed).

Trust, dependency and power relate to different mediating effects (see Table 6). As such, it is important for a buyer to be aware of those characteristics, because all mediating effects need to be addressed in order to have the best effect on supplier performance. 
Mutual trust and clarity of information are significantly correlated. Information sharing relates to trust and the clarity between the supply chain partners. There are three more significant correlations in the model:

a supplier trust in Unilever is significantly correlated with the familiarity with and use of funding

b non-coercive power use is significantly correlated with supplier capabilities

c dependency, both of Unilever on a supplier and mutual dependency, is positively correlated with perception of the costs of implementation.

Table 6 Significant correlations relationship characteristics and intermediate effects

\begin{tabular}{|c|c|c|c|c|c|c|}
\hline \multicolumn{2}{|c|}{ Correlations (Kendall's T) } & \multirow{2}{*}{$\begin{array}{c}\begin{array}{c}\text { Mutual } \\
\text { trust }\end{array} \\
.259 * *\end{array}$} & \multirow{2}{*}{$\begin{array}{l}\text { Supplier } \\
\text { trust in } \\
\text { Unilever }\end{array}$} & \multirow{2}{*}{$\begin{array}{c}\text { Non-coercive } \\
\text { power }\end{array}$} & \multirow{2}{*}{$\begin{array}{l}\text { Unilever } \\
\text { depends on } \\
\text { supplier }\end{array}$} & \multirow[t]{2}{*}{$\begin{array}{c}\text { Mutual } \\
\text { dependency }\end{array}$} \\
\hline $\begin{array}{l}\text { Clarity of } \\
\text { information }\end{array}$ & $\begin{array}{l}\text { Correlation } \\
\text { coefficient }\end{array}$ & & & & & \\
\hline & Sig. (1-tailed) & .042 & & & & \\
\hline & $\mathrm{N}$ & 29 & & & & \\
\hline \multirow{3}{*}{$\begin{array}{l}\text { Helpfulness } \\
\text { of } \\
\text { information }\end{array}$} & $\begin{array}{l}\text { Correlation } \\
\text { coefficient }\end{array}$ & & & $.195^{*}$ & & \\
\hline & Sig. (1-tailed) & & & .092 & & \\
\hline & $\mathrm{N}$ & & & 27 & & \\
\hline \multirow[t]{3}{*}{$\begin{array}{l}\text { Familiar } \\
\text { with funding }\end{array}$} & $\begin{array}{l}\text { Correlation } \\
\text { coefficient }\end{array}$ & & $.222 *$ & & & \\
\hline & Sig. (1-tailed) & & .085 & & & \\
\hline & $\mathrm{N}$ & & 30 & & & \\
\hline \multirow[t]{3}{*}{$\begin{array}{l}\text { Use of } \\
\text { funding }\end{array}$} & $\begin{array}{l}\text { Correlation } \\
\text { coefficient }\end{array}$ & & $.254^{*}$ & & & \\
\hline & Sig. (1-tailed) & & .060 & & & \\
\hline & $\mathrm{N}$ & & 29 & & & \\
\hline \multirow{3}{*}{$\begin{array}{l}\text { "We have to } \\
\text { make large } \\
\text { investments } \\
\text { in order to } \\
\text { comply with } \\
\text { the SAC" }\end{array}$} & $\begin{array}{l}\text { Correlation } \\
\text { coefficient }\end{array}$ & & & & $.226^{*}$ & $.350 * *$ \\
\hline & Sig. (1-tailed) & & & & .068 & .012 \\
\hline & $\mathrm{N}$ & & & & 30 & 30 \\
\hline
\end{tabular}

Notes: *Correlations are significant at a 0.10 level (1-tailed).

**Correlations are significant at a 0.05 level (1-tailed).

***Correlations are significant at a 0.01 level (1-tailed).

Based on the results of the correlation four different regression models were tested.

The first model assesses the unique relations between the governance strategies, trust and clarity in the relationship between a buyer and a supplier. This model explains $60.5 \%$ of the variance in increased clarity in the relationship between a buyer and a supplier (see Table 7). Both the communication strategy and the direct supplier development strategy have a unique effect on increased clarity, but this effect is slightly larger for the direct supplier development strategy. 
Table 7 Multiple regression predicting increased clarity

\begin{tabular}{lcc}
\hline Dependent variable $(n=31)$ & \multicolumn{2}{c}{ Clarity } \\
\hline \multirow{2}{*}{ Constant $)$} & $\beta$ & $R^{2}=0.605$ \\
\cline { 2 - 3 } & $0.449^{* *}$ & Sig. 0.000 \\
\hline Communication & 0.227 & 0.015 \\
Indirect supplier development & $0.461^{* *}$ & 0.214 \\
Direct supplier development & -0.087 & 0.014 \\
Mutual trust & 0.597 \\
\hline
\end{tabular}

Notes: *Regressions are significant at a 0.10 level (1-tailed).

**Regressions are significant at a 0.05 level (1-tailed).

***Regressions are significant at a 0.01 level (1-tailed).

The direct supplier development strategy is the most media-rich strategy. Media richness is related to the ability of a medium to transfer a complex message. Therefore, it is not surprising that the strategy which has the highest potential to transfer a complex message facilitates the highest levels of clarity in the buyer-supplier relationship. Also the communication strategy has a clear unique effect on clarity in the buyer-supplier relationship. This indicates that the frequency and diversity of communication tools, such as email and internet websites, as well as a frequent and diverse use of direct supplier development elements such as training and the use of cross-functional teams, can predict the clarity of a supplier on what is expected with regard to sustainability requirements implementation.

Mutual trust is, contrary to expectations, not uniquely related to increased levels of clarity. Trust is still necessary for supply chain partners to share information, although in itself it does not facilitate clarity. Rather, clarity is facilitated by the way in which the information is shared.

All three governance strategies are also significantly correlated with clarity and capabilities (see Table 5). The indirect supplier development strategy shows the strongest relation with capabilities. In total, the model explains $71.1 \%$ of the variance in capabilities, which facilitates a good predictive power of the development of capabilities for the implementation of sustainability requirements in the relationship between a buyer and supplier.

Table 8 Multiple regression prediction increased capabilities

\begin{tabular}{lcc}
\hline Dependent variable $(n=31)$ & \multicolumn{3}{c}{ Capabilities } \\
\hline \multirow{2}{*}{ Constant $)$} & $\beta$ & $R^{2}=0.711$ \\
\cline { 2 - 3 } & $0.487^{* * *}$ & Sig. 0.000 \\
\hline Communication & 0.266 & 0.003 \\
Indirect supplier development & $0.409^{* *}$ & 0.103 \\
Direct supplier development & 0.079 & 0.010 \\
Non-coercive power & 0.557 \\
\hline
\end{tabular}

Notes: *Regressions are significant at a 0.10 level (1-tailed).

$* *$ Regressions are significant at a 0.05 level (1-tailed).

****Regressions are significant at a 0.01 level (1-tailed). 
Similar to increased clarity, both the communication and the direct supplier development strategies have a unique and direct effect on capabilities.

Surprisingly, when the unique relations are tested in a multiple regression model, indirect supplier development has no significant unique effect on capabilities (see Table 8). This indicates that a part of the correlation between the indirect supplier development strategy and capabilities is not unique to the relation between the two variables, but accounted for by other variables.

No significant unique relation is found between the use of non-coercive power and increased capabilities. This implies that - similar to the relation between mutual trust and clarity - the use of non-coercive power sources in itself is not sufficient to facilitate increased capabilities.

The use of funding is the only mediating effect that has a unique link with improved supplier performance. Therefore, being able to influence suppliers' use of funding has the highest unique effect on improved performance. None of the governance strategies has a unique relation with the use of funding (see Table 9). The use of governance strategies as such is not able to predict the levels of the use of funding by suppliers. Furthermore, the model explains only $20 \%$ of the variance in the use of funding. This means that a large part of the variance in the use of funding is explained by variables other than strategies. Based on the high correlations between the intermediate effects, clarity and capabilities might explain part of the variance as well. Clarity and capabilities are uniquely correlated with the communication and direct supplier development strategies. This could explain why a correlation is found. Although a unique link is missing, governance strategies still influence the use of funding by a supplier.

Table 9 Multiple regression predicting use of funding

\begin{tabular}{lcc}
\hline Dependent variable $(n=31)$ & \multicolumn{2}{c}{ Use of funding } \\
\hline \multirow{2}{*}{ Constant) } & $\beta$ & $R^{2}=0.200$ \\
\cline { 2 - 3 } & 0.250 & Sig. 0.000 \\
\hline Communication & 0.039 & 0.246 \\
Direct supplier development & 0.314 & 0.858 \\
Supplier trust & 0.163 \\
\hline
\end{tabular}

Notes: *Regressions are significant at a 0.10 level (1-tailed).

**Regressions are significant at a 0.05 level (1-tailed).

$* * *$ Regressions are significant at a 0.01 level (1-tailed).

The other aspect of cost perception - the perception that the implementation of sustainability standards is costly - is not uniquely related to improved supplier performance. Only the communication strategy is significantly correlated with this aspect of cost perception - but this is a negative correlation. In order to mediate the cost perception the message should focus more on the potential benefits of the implementation of sustainability standards. Giving explicit attention to the benefits during the implementation of sustainability standards will most likely result in a more balanced cost-benefit perception of the supplier, thus supporting the idea of jointly creating shared value. 
Table 10 Multiple regression predicting perceived costs

\begin{tabular}{lcc}
\hline Dependent variable $(n=31)$ & \multicolumn{2}{c}{ Perception of high costs } \\
\hline \multirow{2}{*}{ Constant $)$} & \multicolumn{2}{c}{$R^{2}=0.418$} \\
\cline { 2 - 3 } & $0.469^{* * *}$ & Sig. 0.000 \\
\hline Communication & 0.147 & 0.008 \\
Unilever dependency & $0.373^{* *}$ & 0.374 \\
Mutual dependency & 0.028 \\
\hline Notes: *Regressions are significant at a 0.10 level (1-tailed). \\
$* *$ Regressions are significant at a 0.05 level (1-tailed). \\
$* * *$ Regressions are significant at a 0.01 level (1-tailed).
\end{tabular}

We also found a unique relation between mutual dependency and the cost perception of the suppliers (see Table 10). The requirements for implementation are initiated from the side of the buyer only - the supplier has no influence on the terms of agreement. This is a coordinating rather than a cooperating strategy and affects the perception of shared value by the supplier. The supplier has to incur costs related to new requirements of the buyer, but has not been able to influence the content of those requirements. As a result, suppliers consider the costs to be higher.

If the content of the message were adjusted to put more emphasis on the benefits of implementation, a more balanced view of costs and benefits could be presented to suppliers. This also shows that shared value does not necessarily consist of providing financial compensation or premium prices paid, but also other types of benefits, like higher yields and yields with higher product quality, which result in better prices.

\section{Conclusions and discussion}

\subsection{The creation of shared value by the use of governance strategies}

All the results are based on a single case study and generalised to reach this conclusion.

This study shows that the implementation of sustainability standards is most successful when it is aiming at collaboratively creating shared value. Apart from better revenues the improved buyer-supplier relationship creates also shared value. This value consists of a competitive advantage that develops through unique capabilities that only exist in the buyer-supplier relationship. One of those unique capabilities is the set of implemented sustainability requirements, which distinguishes the supply chain from other - less sustainable - supply chains. However, this only becomes a competitive advantage once the requirements are fully and correctly implemented. This research confirms that it is important that both parties see the added value of the implementation of sustainability requirements in their supply chain during the implementation. This has an effect on the successful completion of the implementation and of the resulting situation in which shared value and competitive advantage are created.

Governance strategies additionally make suppliers acknowledge the value of the implementation of sustainability requirements. This is two-fold: first, by conveying the message clearly and thereby empowering suppliers to implement the requirements. And second, by emphasising within the message what the benefits of the implementation are 
to the supplier. This implies that clarity, capabilities and cost perception should be addressed simultaneously, in order to show the added value of sustainability implementation to suppliers.

Out of the three strategies in the model, the communication strategy and the direct supplier development strategy are the most successful in involving a supplier in sustainability implementation. Those governance strategies influence the levels of clarity, capabilities and cost perception. However, a combination of these two governance strategies is probably more powerful than each governance strategy used separately. In general, cooperation proves more successful than coordination. This also supports the findings of Muller and Vermeulen (2012).

The following adjusted model is drawn based on the results of the research (Figure 4). Figure 4 shows the same boxes as Figure 1, but only the confirmed relations are displayed.

Figure 4 Confirmed explanatory model of the relation between governance strategies and supplier performance (see online version for colours)

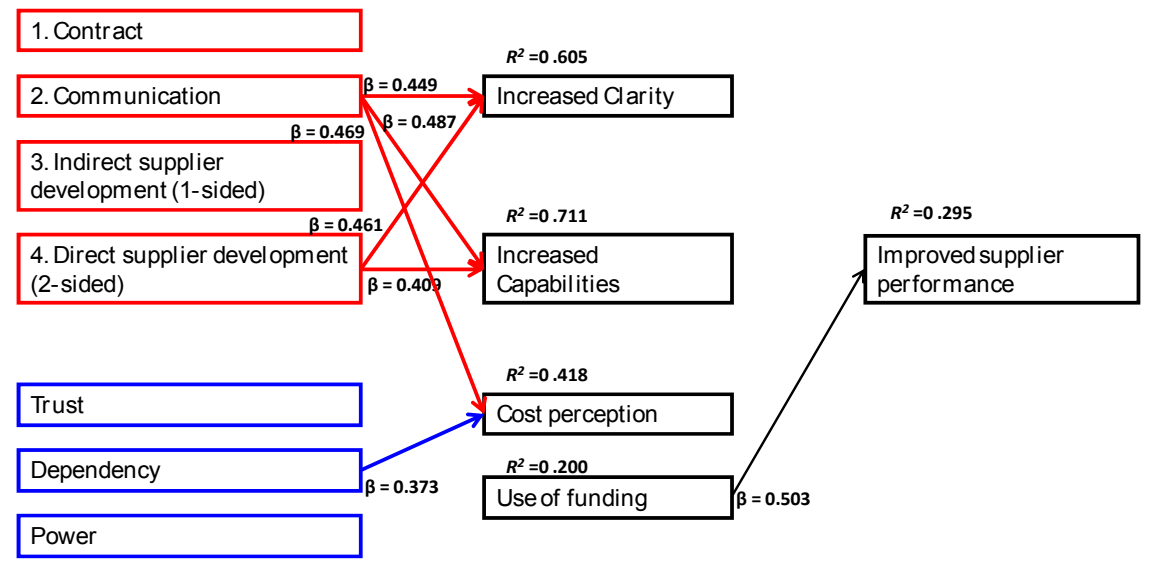

Even though strategies are necessary in order to convey the message to suppliers, the content of the message turns out to be important when it comes to cost perception. Cost perception could be addressed in a broad fashion, but should show to suppliers the advantage of working together. There are several ways in which this could be done. First, the emphasis could be placed on increasing yields and second, buyers could mention sustainability as a criterion for supplier selection. When more buyers start integrating sustainability requirements in their tenders, this truly facilitates a competitive advantage for the supplier that has correctly implemented sustainability requirements in its production processes. Hence, the shared value of the relationship becomes apparent.

\subsection{Limitations to the research}

There are several limitations to this research which affect the conclusions. First and foremost, the sample used in this research consisted of only 32 cases with full information from each of the interacting partners. This severely affects the size of the effects which can be measured. Even though a small sample size is used, many effects 
were still measured. Sample size as such is a limitation, but is not a restraining factor for this research.

Furthermore, this research has been performed at only one company. In order to create a higher validity, the same research could also be undertaken with other companies.

Also, this study is a snapshot of the relationship between the buyer and the supplier. The results of this study link to a much larger literature on the creation of shared value in the buyer-supplier relationship. Hence, even though this is a snapshot, the results gain validity because they support earlier results.

\subsection{Recommendations for future research}

This research focused on the relation between separate governance strategies and the supplier performance on sustainability implementation. One of the conclusions is that different combinations of the aspects of the supplier development strategies could yield the best results on the creation of shared value. However, it is not clear what that combination is. Future research could focus on which combination of governance strategies yields the best results on the implementation of sustainability standards.

In order to improve the current findings, research could be done with a larger sample, in order to detect smaller size effects. Related to that, a more diverse sample could be used to research other background factors, such as supply chain structure.

In addition, since cost-perception was found to be of such importance, future research could focus on the costs which are attached to the different governance strategies and do a cost-benefit analysis on the use of governance strategies for the implementation of sustainability standards and the creation of shared value. This cost-benefit analysis should include also the long-term potential benefits, such as competitive advantage via shared value.

Finally, the creation of shared value requires the development of stable and long-term relations. The reality is that the supplier base changes from time to time and long-term contracts are not very common. At the same time, suppliers sell to multiple buyers. The requirements change for suppliers as well as for buyers. This research looked at the creation of shared value, but another important question is "when shared value is created, how can you ensure that it will remain?". This is an aspect of shared value creation which has not yet been explored and where future research should focus.

\section{References}

Allison, P.D. (1999) Multiple Regression: A Primer, Pine Forge, Thousand Oaks, CA.

Angel, D.P. and Rock, M.T. (2005) 'Global standards and the environmental performance of industry', Environment and Planning A, Vol. 37, No. 11, pp.1903-1918, doi:10.1068/a3788.

Ansett, S. (2007) 'Mind the gap; a journey to sustainable supply chains', Employ Response Rights, Vol. 19, No. 4, pp.295-303, doi:10.1007/s10672-007-9055-x.

Bair, J. and Gereffi, G. (2001) 'Local clusters in global chains: the causes and consequences of export dynamism in Terreon's blue jeans industry', World Development, Vol. 29, No. 11, pp.1885-1903.

Bastl, M. (2013) 'Who's seeking whom? Coalition behaviour of a weaker player in buyer-supplier relationships', Journal of Supply Chain Management, Vol. 49, No. 1, pp.8-28. 
Benton, W.C. and Maloni, M. (2005) 'The influence of power driven buyer/seller relationships on supply chain satisfaction', Journal of Operations Management, Vol. 23, No. 1, pp.1-22, doi:10.1016/j.jom.2004.09.002.

Bitzer, V., Francken, M. and Glasbergen, P. (2008) 'Intersectoral partnerships for a sustainable coffee chain: really addressing sustainability or just picking (coffee) cherries?', Global Environmental Change, Vol. 18, No. 2, pp.271-284, doi:10.1016/j.gloenvcha.2008.01.002.

Carey, S., Lawson, B. and Krause, D.R. (2011) 'Social capital configurations, legal bonds and performance in buyer-supplier relationships', Journal of Operations Management, Vol. 29, No. 4, pp.277-288.

Daft, R.L. and Lengel, R.H. (1986) 'Organizational information requirements, media richness and structural design', Management Science, Vol. 32, No. 5, pp.554-571.

de Bakker, F. and Nijhof, A. (2002) 'Responsible chain management: a capability assessment framework', Business Strategy and the Environment, Vol. 11, No. 1, pp.63-75.

Dolan, C. and Humphrey, J. (2004) 'Changing governance patterns in the trade of fresh vegetables between Africa and the United Kingdom', Environment and Planning A, Vol. 36, No. 3, pp.495-509.

Dyer, J.H. and Nobeoka, K. (2000) 'Creating and managing high-performance knowledge-sharing network: the Toyota case', Strategic Management Journal, Vol. 21, No. 3, pp.345-367.

Fawcett, S.E. (2012) 'Peeking inside the black box: toward and understanding of supply chain collaboration dynamics', The Journal of Supply Chain Management, Vol. 48, No. 1, pp.44-72.

Field, A. (2005) Discovering Statistics Using SPSS, Sage Publications, London.

Frooman, J. (1999) 'Stakeholder influence strategies', The Academy of Management Review, Vol. 24, No. 2, pp.191-205.

Gereffi, G. (1999) 'International trade and industrial upgrading in the apparel commodity chain', Journal of International Economics, Vol. 48, No. 1, pp.37-70.

Gereffi, G., Humphrey, J. and Sturgeon, T. (2005) 'The governance of global value chains', Review of International Political Economy, Vol. 12, No. 1, pp.78-104.

Gligor, D.M. (2012) 'The role of personal relationships in facilitating supply chain communications: a qualitative study', Journal of Supply Chain Management, Vol. 48, No. 1, pp.24-43.

Gold, S., Seuring, S. and Beske, P. (2010) 'Sustainable supply chain management and inter-organizational resources: a literature review', Corporate Social Responsibility and Environmental Management, Vol. 17, No. 4, pp.230-245.

Goldbach, M., Seuring, S. and Back, S. (2003) 'Coordinating sustainable cotton chains for the mass market: the case of the German mail-order business OTTO', Greener Management International, Autumn, Vol. 43, pp.65-78.

Golicic, S.L. and Smith, C.D. (2013) 'A meta-analysis of environmentally sustainable supply chain management practices and firm performance', Journal of Supply Chain Management, Vol. 49, No. 2, pp.78-95.

Hamann, R. (2004) 'Corporate social responsibility, partnerships and institutional change: the case of mining companies in South Africa', Natural Resources Forum, Vol. 28, No. 4, pp.278-290.

Heikkurinen, P. and Forsman-Hugg, S. (2011) 'Strategic corporate responsibility in the food chain', Corporate Social Responsibility and Environmental Management, Vol. 18, pp.306-316.

Hess, M. and Coe, N.M. (2006) 'Making connections: global production networks, standards, and embeddedness in the mobile-telecommunications industry', Environment and Planning A, Vol. 38, No. 7, pp.1205-1227.

Hills, J. and Welford, R. (2005) 'Case study: Coca-Cola and water in India', Corporate Social Responsibility and Environmental Management, Vol. 12, No. 3, pp.168-177.

Hughes, A. (2005) 'Corporate strategy and the management of ethical trade: the case of the UK food and clothing retailers', Environment and Planning A, Vol. 37, No. 7, pp.1145-1163, doi:10.1068/a3753. 
Hult, G.T.M., Ketchen Jr., D.J. and Slater, S.F. (2004) 'Information processing, knowledge development, and strategic supply chain management', Academy of Management Journal, Vol. 47, No. 2, pp.241-253.

Humphrey, J. and Schmitz, H. (2001) 'Governance in global value chains', IDS Bulletin, Vol. 32, No. 3, pp.19-29.

Humphreys, P., Cadden, T., Wen-Li, L. and McHugh, M. (2011) 'An investigation into supplier development activities and their influence on performance in the Chinese electronics industry', Production Planning and Control, Vol. 22, No. 2, pp.137-156.

Hutchins, M.J. and Sutherland, J.W. (2008) 'An exploration of measures of social sustainability and their application to supply chain decisions', Journal of Cleaner Production, Vol. 16, No. 15, pp.1688-1698, doi:10.1016/j.jclepro.2008.06.001.

Krause, D.R., Handfield, R.B. and Tyler, B.B. (2007) 'The relationship between supplier development, commitment, social capital accumulation and performance improvement', Journal of Operations Management, Vol. 25, No. 2, pp.528-545, doi:10.1016/ j.jom.2006.05.007.

Krause, D.R., Scannell, T.V. and Calantone, R.J. (2000) 'A structural analysis of the effectiveness of buying firms' strategies to improve supplier performance', Decision Sciences, Vol. 31, No. 1, pp.33-55, doi:10.1111/j.1540-5915.2000.tb00923.x.

Muller, C. and Vermeulen, W.J.V. (2012) 'Pushing or sharing as value-driven strategies for societal change in global supply chains: two case studies in the British-South African fresh fruit supply chain', Business Strategy and the Environment, Vol. 21, No. 2, pp.127-140.

Opara, L.U. (2002) Traceability in Agriculture and Food Supply Chain: A Review of Basic Concepts, Technological Implications, and Future Prospects [online] http://www.aseanfood.info/Articles/11020000.pdf (accessed 16 January 2012).

Palpacuer, F. (2006) 'The global sourcing patterns of french clothing retailers', Environment and Planning A, Vol. 38, No. 12, pp.2271-2283, doi:10.1068/a3883.

Paulraj, A. (2011) 'Understanding the relationships between internal resources and capabilities, sustainable supply management', Journal of Supply Chain Management, Vol. 47, No. 1, pp.19-37.

Porter, M.E. and Kramer, M.R. (2006) 'Strategy \& society: the link between competitive advantage and corporate social responsibility', Harvard Business Review, Vol. 84, No. 12, pp.78-92.

Porter, M.E. and Kramer, M.R. (2011) 'Creating shared value', Harvard Business Review, Vol. 89, Nos. 1-2, pp.62-77.

Prahinski, C. and Benton, W.C. (2004) 'Supplier evaluations: communication strategies to improve supplier performance', Journal of Operations Management, Vol. 22, No. 1, pp.39-62.

Prahinski, C. and Fan, Y. (2007) 'Supplier evaluations: the role of communication quality', Journal of Supply Chain Management, Vol. 43, No. 3, pp.16-28.

Preuss, L. (2005) 'Rhetoric and reality of corporate greening: a view from the supply chain management function', Business Strategy and the Environment, Vol. 14, No. 3, pp.123-139.

Ras, P.J. and Vermeulen, W.J.V. (2009) 'Sustainable production and the performance of South African entrepreneurs in a global supply chain. The case of South African table grape producers', Sustainable Development, Vol. 17, No. 5, pp.325-340, doi:10.1002/sd.427.

Roca, L.C. and Searcy, C. (2012) 'An analysis of indicators disclosed in corporate sustainability reports', Journal of Cleaner Production, Vol. 20, No. 1, pp.103-118.

Searcy, C. (2011) 'Updating corporate sustainability performance measurement systems', Measuring Business Excellence, Vol. 15, No. 2, pp.44-56.

Seuring, S. and Müller, M. (2008) 'From a literature review to a conceptual framework for sustainable supply chain management', Journal of Cleaner Production, Vol. 16, No. 15, pp.1699-1710. 
Skandrani, H., Triki, A. and Baratli, B. (2011) 'Trust in supply chains, meanings, determinants and demonstrations; a qualitative study in an emerging market context', Qualitative Market Research: An International Journal, Vol. 14, No. 4, pp.391-409.

Terpend, R. and Ashenbaum, B. (2012) 'The intersection of power, trust and supplier network size: implications for supplier performance', Journal of Supply Chain Management, Vol. 48, No. 3, pp.52-77.

Terpend, R., Krause, D.R. and Dooley, K.J. (2011) 'Managing buyer-supplier relationships: empirical patterns of strategy formulation in industrial purchasing', Journal of Supply Chain Management, Vol. 47, No. 1, pp.73-94.

Unilever (2010a) Annual Report: Creating a Better Future Every Day, Unilever.

Unilever (2010b) Unilever Sustainable Agriculture Code, Unilever.

Unilever (2010c) Unilever Sustainable Living Plan, Unilever.

van der Heijden, A., Driessen, P.P.J. and Cramer, J.M. (2010) 'Making sense of corporate social responsibility: exploring organizational processes and strategies', Journal of Cleaner Production, Vol. 18, No. 18, pp.1787-1796.

van Huijstee, M.M. (2010) Business and NGOs in Interaction. A Quest for Corporate Social Responsibility, Copernicus Institute for Sustainable Development and Innovation, Utrecht University.

Vermeulen, W.J.V. (2010) 'Sustainable supply chain governance systems: conditions for effective market based governance in global trade', Progress in Industrial Ecology - An International Journal, Vol. 7, No. 2, pp.138-161.

Vermeulen, W.J.V. (2015) 'Self-governance for sustainable global supply chains: can it deliver the impacts needed?', Business Strategy and the Environment, Vol. 24, No. 3, pp.73-85, doi:10.1002/bse.1804.

Vermeulen, W.J.V. and Ras, P.J. (2006) 'The challenge of greening global product chains: meeting both ends', Sustainable Development, Vol. 14, No. 4, pp.245-256.

Wagner, S.M. and Krause, D.R. (2009) 'Supplier development: communication approaches, activities and goals', International Journal of Production Research, Vol. 47, No. 12, pp.3161-3177. 